\title{
Testicular Lymphoma
}

National Cancer Institute

\section{Source}

National Cancer Institute. Testicular Lymphoma. NCI Thesaurus. Code C6810.

A lymphoma that arises from the testis and is not associated with lymphoma in another anatomic site. 